\title{
Translation and Convergence Culture: German Renderings of Uncle Tom's Cabin
}

\author{
Annika Rosbach
}

Rather than being a phenomenon unique to $21^{\text {st }}$-century new media culture, translations have always been the epitome of Jenkins's concept of 'convergence culture' (Jenkins 2006). In translation, cultural content is rendered from one medium, i.e. language, into another and then 'migrates' across national borders to reach new 'consumers.' In this process the binary opposition of 'original' and 'translation' is dissolved, bringing forth an artefact of its own. The new text is not simply the same text in a different language but a contact zone of cultures and languages. Thus, convergence here is not a process of merging but produces a zone of cultural encounter which Homi Bhabha in The Location of Culture (1994) has termed a 'third space.' In this space, cultural differences, if not contradictions, are not homogenized but create frictions and need to be 'negotiated.' The translational activity therefore is one of debating the differences in cultures and hence languages. Socalled 'translation problems,' then, are those cultural differences which are not easily negotiable or 'convergable' but do nevertheless require some sort of solution in the form of translational strategies. If translations as contact zones "provide the terrain for [...] innovative sites of collaboration and contestation" (Bhabha 1994, 1-2), then it is primarily the translator, as the central actor in this cultural negotiation, who decides which translation strategy wins over other possible solutions. 
Annika Rosbach

Mostly 'invisible'1 to the reader, the translator, through his linguistic choices, actively and powerfully participates in meaning-making and in preparing the text for reception. To trace these effects of cultural negotiation in translation not only offers new perspectives on the texts under study but also provides insight into the cultures and cultural practices involved. Aiming at revealing these effects, this article investigates translation strategies used in the transformation of the African American vernacular in Harriet Beecher Stowe's Uncle Tom's Cabin (1852) into German.

\section{Uncle Tom's Cabin, Linguistic Identities, and Racial Stereotypes}

Literary dialects specifically lend themselves to investigations into the effects of translational negotiation because, in both translation theory and practice, they are recognized as 'problematic' in terms of their cultural, regional, and social specificity. In the absence of 'equivalents' 2 in the target language, literary dialects are often deemed untranslatable (House 1973; Landers 2001). Uncle Tom's Cabin, first published in 1852, is an interesting case because it is not only considered the internationally best-known and most widely-read literary representation of Black characters and African American English ${ }^{3}$ by an American author (Paul 2005, 127) but has also seen an extraordinarily rich (translational) reception in Germany.

In sociolinguistics, the link between language use and both individual and group ethnic identity is a commonly acknowledged fact (Joseph 2004; Edwards 2009; Fishman 2010 and 2011). In the 20th century, several sociolinguistic studies in urban and rural African American communities in the United States have confirmed this link for African American English (Wolfram 1969; Labov 1972; Pederson 1983; Morgan 1994; Green 2002). Additionally, in Language, Discourse and Power in African American Culture (2002) Morgan describes the value of the Black vernacu-

1 According to Lawrence Venuti, in the dominating British and American (and no less the German) translation culture the act of translation is concealed through the "reduction of the foreign text to receiving cultural values" $(2008,15)$. Referring to Friedrich Schleiermacher, he terms this strategy "domestication" (15).

2 The notion of textual 'equivalence' is a highly contested one in translation studies (Snell-Hornby 1995; Bassnett 2002; Pym 2010; Baker 2011). For the purpose of this article, the term is not used to evaluate a translation as being right or wrong, adequate or inadequate, but simply to indicate that there is no German language variety comparable to African American English, either in structure, or genesis, or status.

3 In this article, the term 'African American English' subsumes the different superregional variants of the variety of American English primarily spoken by (i.e. not exclusively and not by all) Americans of African descent in the United States of America which are, both in academic and nonacademic discourses, commonly associated with Afro-American ethnic identity and culture. It is understood as a rule-based language system with fixed phonological, morphological, syntactic, semantic, and lexical structures (Green 2002, 1-2) - thus expressly not as a deficient deviation from American English. 
lar (together with conversational forms of indirectness typical of Afro-American speech) as a 'counterlanguage' in the interaction with Whites. Similarly, in literary studies, dialect in general (Mace 1987; Mpoche and Mbuh 2006; Leech and Short 2007) and the African American English ethnolect ${ }^{4}$ in particular (Holton 1984; Minnick 2004) have been recognized as an important communicative as well as semiotic device used in works of fiction not only to create authenticity but also to construct character identity. Accordingly, literary dialect is perceived as being reflective of character behaviour in general and as indicating individual character traits as well as character relations. The role of African American English in the process of claiming or maintaining a decidedly Black identity has come to feature prominently in works by African American authors of the Harlem Renaissance, such as Langston Hughes, Claude McKay, Jane Toomer, Rudolph Fisher, Richard Wright, and Zora Neale Hurston, or more recently in Alice Walker's and Toni Morrison's novels.

A contested piece of literature with regard to its aesthetic value both among its contemporaries and critics in the 20 th century (Gossett 1985; Sundquist 1986), Uncle Tom's Cabin has also been criticized for its inauthenticity with regard to language use (McDowell 1931; Holton 1984, 69-71) and its overall stereotypical, even romantic racialist depiction of Black slaves (Cantave 2000; Frederickson 1971). Certainly less authentic in her representation of the Black vernacular spoken in the

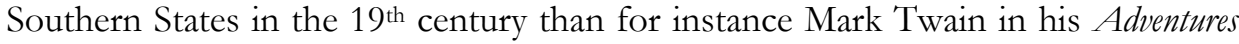
of Huckleberry Finn (1884), Stowe had no profound knowledge of African American English. Born and raised in the non-slave state of Connecticut, she spent most of her adult life in the non-slave state of Maine where the Black community was a very small one. She therefore had to rely on what she had heard from friends and relatives and her extensive reading of novels and abolitionist magazines (Holton 1984, 69). However, based on the understanding of literary representations of dialects in general and African American English in particular as stylistic devices and therefore the author's "suggestions rather than authentic representations of the speech of a particular group of speakers" (Holton 57), for the purpose of this article I will content myself with discussing how Stowe presented Black speech rather than evaluate its authenticity. Also, like most literary representations of African

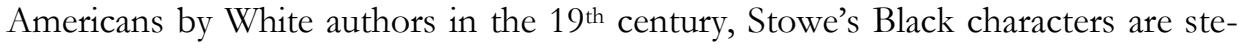
reotyped. Uncle Tom's Cabin depicts at least four of the seven most widespread preCivil-War stereotypes about Blacks in America identified by literary critic Sterling Brown in his 1933 article "Negro Characters as Seen by White Authors": the "Tragic Mulatto" (Eliza and George), the seemingly "Contented Slave" (Uncle

4 In accordance with the definition of African American English as a language in its own right, I will refer to the Black vernacular as an ethnolect rather than as a dialect. While the term 'dialect,' in its common usage, implies the status of a variety as a deviation from an existing, superior language, the term 'ethnolect' more adequately reflects linguistic autonomy as well as the identificational dimension of language use. 
Tom, Aunt Chloe, Dinah, Mammy), the "Comic Negro" (Topsy), and the "Brute" (Sambo and Quimbo) (qtd. in Holton 59). However, what distinguishes Uncle Tom's Cabin from other works of the time is that this stereotyping is also shown linguistically: while Stowe has the first group speak Standardized ${ }^{5}$ American English throughout the entire novel, the last group's speech is marked by heavy use of the vernacular. In between these two extremes, the vernacularization of other characters' speech varies in intensity. Even though Stowe's Black characters may lack individuality, her nuanced linguistic representation is effective in that, on the textual level, it constructs character relations and problematizes the question of ethnic identity and identification under slavery. The following analysis uses excerpts from the English source text which are both symptomatic for the way the characters employ African American English throughout the novel and show how, in their linguistic representation, Stowe moves beyond her stereotypes.

\section{Speaking Types}

Against all critique regarding aesthetic value, Stowe's depiction of slavery in the Southern States of America in the middle of the $19^{\text {th }}$ century and especially of its effects on society - Black and White ${ }^{6}$ - relies on a complex system of character contrast and interrelation. Within this system, language, albeit stereotyped, functions both as a stylistic and a structural element within the text and with regard to the reader-text relationship, hence reader reception. On the textual level, the degree to which African-American English is used is, on the one hand, an implication of a character's self-positioning with regard to the Black community and, on the other hand, serves to evoke a contrast between positive and negative Black characters. Moreover, the use of ethnolect features in Uncle Tom's Cabin is a marker for the level of education the characters have received, and also a humorous element. Beyond the character level, vernacular usage in Uncle Tom's Cabin adds a linguistic dimension to one of the novel's major strengths, namely to create powerful readertext-relationships through empathy and alienation. This is most evident when comparing reader perceptions of positive characters like Uncle Tom, whose direct speech is only slightly vernacularized, and negative characters like Sambo and Quimbo, who speak heavily marked African American English.

The first Black character Stowe introduces the reader to right in chapter one is Mrs. Shelby's maid Eliza. Together with her husband George and, later in the novel, Cassy and Emmeline, she is representative of the narrative's "Tragic Mulat-

5 Instead of the commonly used term 'Standard American English,' in this article generally accepted language norms will be referred to as 'Standardized,' since standardization is a process rather than an inherent fact.

6 To indicate that 'Black' and 'White' here do not simply refer to skin colour but to related concepts of ethnic culture, language, and identification, both terms are capitalized. 
to[es]" (qtd. in Holton 1984, 59) (and, for that matter, quadroons 7 ), who all speak Standardized American English throughout the entire novel. For these characters, indexing Whiteness through language use expresses their strong desire for freedom and acceptance in mainstream, i.e. White society, a desire that all of them give way to by escaping to the Northern States. At the same time, linguistic Whiteness positions these characters as outsiders to the novel's Black community, whereas vernacular use projects a facet of Black identity and ethnic solidarity and thus supports community building and maintenance.

Within the novel's Black communal spaces - the cabin on the Shelby plantation and the kitchen in St. Clare's house - the mostly female house slaves, who like Tom's wife Aunt Chloe on the Shelby plantation, the cook Dinah, or the maid Mammy in St. Clare's house seem 'content' with their work-intensive yet secure lives, are through their language clearly distinguishable from the White characters they interact with. In Aunt Chloe's case, the cabin on the Shelby plantation stands as a symbol for the idyllic, yet fragile family-like community of the Shelby slaves, which Chloe holds together by creating a warm and homely space amidst the bleakness of slavery. For Dinah, the head cook in St. Clare's household, 'her' kitchen represents a space of mental dominance, which she maintains despite Miss Ophelia's attempts to reorganize the kitchen to her taste. The effect of linguistic contrasting of Black and White characters then is that, on the one hand, Whites are all the more outsiders, even intruders into the Black characters' spaces of domesticity, while, on the other hand, the sense of Black community within these spaces is strengthened.

Following the North American humorous dialect tradition, the vernacularized speech of other characters in Uncle Tom's Cabin adds to their humorous, comical depiction. The little, wild slave girl Topsy, for instance, is introduced to the reader as a filthy, ragged, "goblin-like" (Stowe 1852/2010, 217) figure with a talent for entertaining her White masters with odd singing and dancing. Her heavily marked speech not only supports her generally comical depiction but evokes a pitiable effect as well: having been raised like a farm animal and denied knowledge of her parents' identity as well as any sort of (Christian) education and personal development - as her language gives proof of (e.g. Stowe 1852/2010, 'Chapter XX') -, the physical abuse she has suffered is multiplied by mental and spiritual abuse. Making a child the symbol of such a crime against humanity supported Stowe's appeal to mothers in particular and women in general, whose responsibility Stowe saw in ensuring that morality and Christian values are lived by within the home and from there are transferred to the public space.

However, Stowe's representation of Black speech is most effective when it is used to reflect individual character traits as in Uncle Tom's case and, particularly,

7 The term 'mulatto' refers to a person with one Black and one White parent, 'quadroon' to a person with one-quarter Black ancestry. 
when it emphasizes the potential for moral character development as in Sambo and Quimbo's speech. The central characteristics of Stowe's protagonist Uncle Tom are his religiosity and his strength of faith, which allow him to assume the role of a missionary trying to spread God's love and benevolence among the people, Black and White, thereby seeking to alleviate the suffering under slavery and to increase the hope of salvation. In the following direct speech excerpt, after having been cruelly whipped on his third owner Legree's plantation for helping a weaker female slave named Cassy pick cotton, Tom urges Cassy, who in the face of slavery seems to have given up all hope for her own fate as well as her belief in God, not to let the sins of others (i.e. slave owners like Legree) turn her into a sinner herself. The portrayal of Tom submitting to being beaten for his beliefs and acts of religious charity, rather than actively seeking his own freedom, has been criticized as too passive and submissive a representation and has been viewed as an affirmation rather than a rejection of slavery (Cantave 2010). Such a reading neglects both Tom's Christ-like selfless love even in the face of evil and personal trial as well as the fact that, while he himself chooses passive resistance, he does encourage and support others (Eliza, Cassy, and Emmeline) in their attempts to escape. In Tom, the virtue of Christian charity is detached from his minority status and exemplifies a model of behaviour to be adopted by Black and White. After all, as Stowe's ubiquitous appeals to her readership's Christian morale imply, she regarded a transformation through Christian love as indispensable for the successful abolishment of slavery. The metaphorical transcendence of race in character behaviour is also reflected in a reduced 'Blackness,' i.e. reduced vernacularization, of Tom's speech:

"Poor critturs!" said Tom, - "what made 'em cruel? - and if I give out, I shall get used to't, and grow, little by little, just like 'em! No, no, Missis! I've lost everything, - wife, and children, and home and a kind Mas'r, and he would have set me free, if he'd only lived a week longer; I've lost everything in this world, and it's clean gone, forever, - and now I can't lose Heaven, too; no I can't get to be wicked, besides all!' [...]

"Missis," said Tom, after a while, "I can see that, some how, you're quite 'bove me in everything; but there's one thing Missis might learn even from poor Tom. Ye said the Lord took sides against us, because he lets us be 'bused and knocked round; but ye see what come on his own Son, - the blessed Lord of Glory, - wan't he allays poor? And have we, any on us, yet come so low as he come? 'The Lord han't forgot us, - I'm sartin' o' that ar'. If we suffer with him, we shall also reign, Scripture says; but, if we deny Him, he also will deny us. Didn't they all suffer? - the Lord and all his? It tells how they was stoned and sawn asunder, and wandered about in sheep-skins and goat-skins, and was destitute, afflicted, tormented. Sufferin' an't no reason to make us think the Lord's turned agin us; but jest the contrary, if only we hold to him, and doesn't give up to sin." (Stowe 1852/2010, 329-330) 
The most prominent linguistic feature of Tom - both in this excerpt and in the entire novel - is the dropping of unstressed syllables ('bused or 'bove), consonants ('em, o', wan't, han't), vowels ('t), and consonant vowel groups (Mas'r). Moreover, his speech is marked by forms of so-called eye dialect, i.e. deviations from the standardized spelling that do not necessarily affect pronunciation, as in critturs (creatures), allays (always), sartin' (certain), jest (just), and repeatedly in ye instead of you. The latter is the most characteristic marker of Black speech in Uncle Tom's Cabin but does not consistently replace you. Aside from eye dialect forms and syllable/sound omissions, there are occasional forms of subject-verb disagreement (e.g. in they was and if we ... doesn't), nasalized ing-endings (sufferin'), double negatives (an't no reason, with an't instead of the more commonly used ain't as characteristic negator in African American English), and left-out markers of the past participle has, as for instance in "And have we, any on us, yet come so low as he come?" and "but ye see what come on his own Son." With "get to be wicked" Tom uses the verbal marker be, which today is one of the features most commonly associated with African American English and signals the habitual occurrence of an event or state. Another prominent feature of African American English in Uncle Tom's Cabin is ar', which most often, as in the example above, replaces there.

By having Tom speak more like her positive White characters - i.e. 'humane' slave masters like the Shelbys or August St. Clare as opposed to wicked characters like Mr. Haley, who speaks with a strong Southern accent - Stowe reduces the distance and inequality between Tom and these Whites linguistically, thus making it easier for her readers to feel sympathy for Tom. In support of Stowe's abolitionist stance, this linguistic quasi-equality can be read as a metaphor for the general equality of Black and White. The residual non-standard features in Tom's speech do not give proof of his racial and/or mental inferiority but provide authenticity by hinting at the limitation, if not total lack of access to education for slaves. Thereby, Tom's metaphorical linguistic transcendence of race is based in reality where he has a minority status.

In contrast to Tom's speech, Simon Legree's principal overseers and themselves slaves Sambo and Quimbo, whom "Legree had trained [...] in savageness and brutality as systematically as he had his bull-dogs" (Stowe 1852/2010, 315), not only use vernacular features with a much higher frequency but also in greater variety than Tom does. ${ }^{8}$

"What the devil's got into Tom?" Legree said to Sambo. [...]

"Dunno, Mas'r; gwine to run off, mebbe."

"Like to see him try that," said Legree, with a savage grin, "wouldn't we, Sambo?”

8 The direct speech passage used as an example in this article represents the longest continuous stretch of dialogue of Sambo and Quimbo, who, as minor characters, are given much fewer opportunities for verbal expression than Tom, for instance. 
“Guess we would! Haw! haw! ho! [...] Lord, de fun! To see him stickin' in de mud, - chasin' and tarin' through de bushes, dogs a holdin' on to him! Lord, I laughed fit to split, dat ar time we cotched Molly. I thought they'd a had her all stripped up afore I could get 'em off. She car's de marks o' dat ar spree yet." (Stowe 1852/2010, 358)

Where Tom uses the Standardized American English voiced th, Sambo and Quimbo's speech displays a voiced $d$ (e.g. in de or dat), one of the most prominent phonological features associated with African American English - even though this marker, like others, is not used consistently throughout the novel. Like in Tom's speech, Stowe uses nasalized ing-endings (as in stickin', chasin', or gwine), drops unstressed syllables ('count), consonants $\left(0^{\prime}\right)$, and consonant vowel groups as in car's (carries). Most striking is Sambo and Quimbo's extensive use of eye dialect forms, e.g. in dunno (don't know), mebbe (maybe), sertain' (certainly), drefful (dreadful), and ye (you). On the syntax level Sambo and Quimbo frequently form disagreeing subject-verb constructions (we's been) as well as double negatives, which are not represented in the short excerpt above. A vernacular feature not found in Tom's direct speech is their use of the reduced auxiliary form $a$ for have as in "they'd $a$ had."

In keeping with the Black literary stereotypes as proposed by Sterling Brown, Sambo and Quimbo represent the "Brute[s]" (qtd. in Holton 1984, 59) who always and opportunistically side with whoever seems to be most advantageous to them even if that means allying themselves with brutal slave owners. By engaging with the two in a kind of privileged familiarity, while at the same time playing them off against each other, Legree ensures their dependence on him and hence the maintenance of the slavery microcosm on his plantation. While continuing her portrayal of the physical and emotional sufferings of slaves, with the story on Legree's plantation Stowe points to the highly demoralizing effect of chattel slavery not only on the White oppressors but also on the oppressed themselves, who like Sambo and Quimbo turn against fellow Blacks. The heavily vernacularized speech of the two then has a double effect: while serving to emphasize the brutality and cruelty of the characters in contrast to Tom's charitable nature, it also creates a linguistic distance between the fictional world and the reader whose reading pace and ease are disturbed by the natural urge to subvocalize when reading vernacular speech. The use of non-standard language in fiction not only implies "remoteness from the author's own language, [but also] from the central standards of judgment in a novel" (Leech and Short 2007, 137), thus complicating the reader's identification with or feelings of sympathy and empathy for Sambo and Quimbo. The supposition that the heightened concentration of markers of the vernacular - among other (non-) linguistic features in the novel - serves as a deliberate strategy to signify the immoral, is supported by the observation that later in the novel, when Sambo and Quimbo repent and thereby find a way towards a more Christian behaviour, their language also suddenly changes into almost unmarked Standardized American 
English. Even if the further progress of Sambo and Quimbo's moral development remains unknown to the reader, Stowe points to her characters' potential for moral improvement, thereby moving them beyond their initial stereotyped depiction. With regard to reader reception, alteration in vernacular use here contributes greatly to the reader's awareness of those moral standards Stowe considered worth following. Relieved from the need to decipher heavy vernacular, the reader instantly understands Stowe's plea for a change towards Christian humanity. While the Black vernacular serves various functions in Uncle Tom's Cabin, the following analysis of the novel's translation history in Germany reveals a complete loss of these functions in German translations.

\section{Silencing Blackness}

The great number of German-language versions of Uncle Tom's Cabin reflects the initial and continuous success of the novel in Germany as well as the surrounding Germanophone countries of Austria, Switzerland, and Belgium. The first translation was published in 1852, only a few months after the English version's appearance first in Great Britain and then in the USA, under the title Onkel Tom's Hütte oder Negerleben in den Sclavenstaaten des freien Nordamerika (Uncle Tom's Cabin or Negro Life in the Slave States of the Free North America; translation mine). Heike Paul counts 29 more editions for the years 1852 until 1854 alone, followed by 18 new editions until the end of the $19^{\text {th }}$ century $(2005,128)$. For the period from the turn of the $20^{\text {th }}$ century until the present day, the online catalogue of the German National Library lists 129 different versions, for the most part produced by publishers based in Germany. However, from the beginning of its translation history in Germany, the novel has mutated into a children's book, abridged and (colourfully) illustrated. Even of those versions not published as 'adaptation for children and youth,' qua number of pages, only around a dozen can claim completeness and translation status. The majority of the German-language versions in the $19^{\text {th }}$ century was published as 'abridged,' 'retold,' and 'freely adapted on the basis of the English original' editions. This trend extends well into the $20^{\text {th }}$ and the $21^{\text {st }}$ centuries. According to the data in the online catalogue of the German National Library, only four editions claim to be translations, either newly translated or rendered into German on the basis of an earlier translation, namely the versions by Hildegard Blomeyer (first published in 1949), Werner Buhre (1950), Wieland Herzfelde (1952), and Susanne Althoetmar-Smarczyk (1994). Interestingly, in adding 'bearbeitet von' (adapted by) to the title information, one of the first German-language versions of Uncle Tom's Cabin admits adaptation but in its introduction nevertheless claims truthfulness:

The English original $[\ldots]$ is 329 densely printed octavo pages long; and a faithful and complete translation of it would hardly please the German reader; if only because of the many, lengthy conversations in provincial 
dialect and Nigger English [...] which to the German reader must be tiring since they introduce him to ideas which can be of no interest to him. [...] It will suffice to give him [the German reader] an overall impression [...] [,] a shortened German adaptation in which, however, nothing essential was left out [...]. (Ungewitter in Stowe 1852, 6-7; translation mine)

The translator, a Dr. Ungewitter, identifies the Black vernacular as the novel's most 'problematic' cultural difference. His solution is to leave out dialogue passages entirely and provide the reader with summarized accounts of Black characters' direct speech. In a reader-oriented approach, he reduces the foreignness of Stowe's text by means of linguistic standardization to make it more accessible for the German readership. Ungewitter justifies this strategy by pointing to the dispensability of the vernacular for plot and meaning - and thus makes a claim that has already been proven wrong by the above analysis of the specific functions of Black ethnolect in the novel. Nevertheless, translators and adapters alike have chosen to follow the translation strategy of Ungewitter and have 'silenced' the African American English by either leaving out direct speech of Black characters altogether, or paraphrasing it in indirect speech, or rendering it in Standardized German. The most recent German translation by Susanne Althoetmar-Smarczyk attempts cautious creative innovation through the occasional use of colloquialisms in the form of contracted verb-object constructions (ich habs instead of $i c h$ habe es) and dropped (end-)vowels (eins instead of eines, or wär instead of wäre). However, in German these forms are all absolutely unmarked in terms of region, class, or status. In translation, Uncle Tom is denied linguistic differentiation from the other Black characters altogether, except for Althoetmar-Smarczyk's rendering where the occasional occurrence of subjunctive forms in Tom's speech moves him into the linguistic sphere pertaining to the distinctive vocabulary of the educated class. ${ }^{9}$

In the case of Uncle Tom's Cabin, linguistic standardization and hence the 'domestication' of African American English in German translations has a positive side effect to it, namely the suspension of linguistic differences between the Black and the White characters. Blacks and Whites are presented as equals in terms of linguistic and mental capacity - certainly an effect that would have served the underlying abolitionist intentions well. However, by deconstructing the functions of the vernacular both on the textual and the reader-response level, the German translations follow a target-culture-oriented approach in which Stowe's characters, who are originally linguistically individualized within the limits of common stereotypes, blur into 'the Blacks' as opposed to 'the Whites.' While this is less problematic in the reception of Tom's character since he is characterized primarily through his actions, the reader's understanding of other characters must rely on the narrator's indirect characterizations, which, due to omissions of whole scenes in some

9 For example, "Sie haben gesagt, daß Gott gegen uns Partei ergriffen habe, weil er uns mißhandeln und schlagen läßt" (Stowe 1994/2009, 417; emphasis added). 
translations - even those translations that claim completeness -, sometimes do not even provide enough ground for reader orientation.

The deliberate silencing of African American English as an aspect of Black ethnic identity in the first translations of Uncle Tom's Cabin certainly fits into the context of German 19th-century racial discourse. After all, through standardization, the language of perceived White superiority - in this case German - was forced upon Black characters, thereby disavowing the eligibility of African American English as a language in its own right and denying racial equality. At the same time, linguistic standardization and hence the relegation of Blackness as 'the Other' to the sphere of what was known to the German readership facilitated the replacement processes Heike Paul (2005) describes in her study on the reception of Uncle Tom's Cabin in Germany: where Stowe wrote about racial inequality, German readers very often constructed a race-class analogy, replacing slavery with class hierarchies and political, social, and economic inequality in post-1848 revolutionary Germany. To readers in Germany Stowe's novel served as a model to explain the negative experiences of German immigrants in America who, allegedly, were not only discriminated against but treated like Blacks ${ }^{10}$ by a reputedly xenophobic American society (Paul 133-156). Thus, in the German imagination the American experience of Black slavery stepped back behind identification with the universal experience of the 'un-free.'

But how does Uncle Tom, whose German voice has hardly changed over the past 160 years, fit into the German literary/translation culture of the $21^{\text {st }}$ century? Is standardization of minority languages in translation still a suitable strategy against the backdrop of a multicultural German society? And finally, does the dissolution of cultural difference serve or limit 'political correctness' in literature? ${ }^{11}$ To approach and answer these very practical questions, Bhabha's notion of cultural translation is helpful: just as cultural contact zones are never static but are instead defined by the historical, political, economic, and social contexts in which they emerge, so negotiations of cultural difference within these 'third spaces' need to be in constant flux, adapting to the circumstances that feed these negotiations. Likewise, the negotiation of translational problems, which are greater the wider the cultural gap between the source culture and the receiving culture is, must not rely on past solutions but needs to assume responsibility for the current implications of these problems.

10 According to (fictional) travel accounts by German immigrants published in the 1850s and 1860s, there were cases of Germans being sold into slavery. Prominent examples are Franz von Elling's Des Lebens Wandlungen (1854) and Theodor Griesinger's Freibeit und Sklaverei unter dem Sternenbanner (1862).

${ }^{11}$ In 2013, a public debate was sparked off about the question whether terms like 'Neger' (Nigger) and negative depictions of African Americans in German (translations of) children's books written in the $19^{\text {th }}$ and the early $20^{\text {th }}$ centuries should be replaced by non-discriminatory terms and representations. 


\section{Conclusion}

The representation of Black speech in Uncle Tom's Cabin conveys meanings relevant to plot on the textual level and has implications for reader reception. Within the text, the nuanced use of the vernacular helps define the relation between Black and White and among slaves. In terms of an ethnic self-image, the vernacular becomes a symbol of the shared, communal identity, while at the same time functioning as a counter-hegemonic sign. Such a linguistic reading of direct speech in Uncle Tom's Cabin therefore allows for a more favourable reading than has been presented by many critics - certainly within the limits of legitimate criticism with regard to stereotyped representations. Beyond the textual level, linguistic differentiation in Uncle Tom's Cabin serves to stimulate reader response with regard to Blacks and the system of slavery. Through predominant standardization of the vernacular, the examined German translations deconstructed both of these functions in favour of better accessibility and readability for the German readership. At least in the $19^{\text {th }}$ century, this resulted in a reading very different from the way Americans understood the novel. These semantic shifts in translation are the product of translation processes, by means of which converging cultures and languages are negotiated and which "carr[y] the burden of meaning" (Bhabha 1994, 38) required to be translated across, or despite, cultural differences. Within this 'third space,' translators are key actors because, as translation theorist André Lefevere asserts, they have the power to "manipulate the originals they work with to some extent, usually to make them fit in with the dominant, or one of the dominant ideological and poetological currents of their time" $(1992,8)$. For the first translators of Uncle Tom's Cabin poetological considerations played an important role in their renderings of the novel's ethnolect features - after all German literary realists were only starting to experiment with German dialects around the middle of the 19th century. At the same time they were clearly guided by ideological considerations at a time when Germans heavily criticized slavery as practised in the Southern United States as radical and institutionalized oppression, but were themselves far from recognizing Blacks as their equals.

Since translations, as this article has sought to show, are not likenesses of an 'original' in a different language but rewritings, and according to Lefevere even "potentially the most influential" ones $(1992,9)$, any study of the reception of a piece of literature beyond its culture of origin needs to begin with its translation(s) and the factors involved in the translation process. At the same time, translations, as in the case of Uncle Tom's Cabin, provide new perspectives on the reading of works of literature and thus continue to be worth studying - not as inferior derivatives of an 'original' but as rewritings in their own right. For translation practice, analyses like the above can help to find new approaches in dealing with literary language varieties based on a thorough understanding of their functions and effects. While Jenkins's theory of convergence culture may not offer new insights into the study of translations in general, it adds to the vocabulary of existing theo- 
ries of culture, in particular Homi Bhabha's concept of the 'third space,' which can be fruitfully applied to describe translations as dynamic zones of cultural encounter.

\section{Works Cited}

\section{Primary Sources}

Stowe, Harriet Beecher. Uncle Tom's Cabin. 1852. New York and London: W.W. Norton \& Company, 2010.

---. Onkel Tom's Hütte oder Negerleben in den Sclavenstaaten des freien Nordamerika. Übersetzt und bearbeitet von Ungewitter. Wien and Leipzig: Pest, 1852.

---. Onkel Toms Hütte. Trans. Hildegard Blomeyer. Köln: Kiepenheuer Witsch, 1949.

---. Onkel Toms Hütte. Aus dem Englischen neu übertragen von Werner Buhre. Bamberg: Baessler, 1950.

---. Onkel Toms Hütte. Übersetzt vom Hrsg. unter Verwendung einer anonymen Übersetzung aus dem Jahre 1854. Trans. Wieland Herzfelde. Berlin: Verlag Neues Leben, 1952.

---. Onkel Toms Hütte. 1994. Trans. Susanne Althoetmar-Smarczyk. München: dtv, 2009.

\section{Secondary Sources}

Baker, Mona. In Other Words: A Coursebook on Translation. 1992. London and New York: Routledge, 2011.

Bassnett, Susan. Translation Studies. 1980. London and New York: Routledge, 2002.

Bhabha, Homi K. The Location of Culture. London and New York: Routledge, 1994.

Cantave, Sophia. "Who Gets to Create the Lasting Images? The Problem of Black Representation in Uncle Tom's Cabin." 2000. Uncle Tom's Cabin. New York and London: W.W. Norton \& Company, 2010. 582-595.

Edwards, John R. Language and Identity: An Introduction. Cambridge: Cambridge UP, 2009.

Fishman, Joshua A., ed. Handbook of Language and Ethnic Identity. 1. Disciplinary and Regional Perspectives. Oxford: Oxford UP, 2010.

---, ed. Handbook of Language and Ethnic Identity. 2. The Success-Failure Continum in Language and Ethnic Identity Efforts. Oxford: Oxford UP, 2011. 
Frederickson, George M. "Uncle Tom and the Anglo-Saxons: Romantic Racialism in the North." 1971. Uncle Tom's Cabin. New York and London: W.W. Norton \& Company, 2010. 464-473.

Gossett, Thomas F. Uncle Tom's Cabin and American Culture. Dallas: Southern Methodist UP, 1985.

Green, Lisa J. African American English: A Linguistic Introduction. Cambridge: Cambridge UP, 2002.

Holton, Sylvia Wallace. Down Home and Uptown: The Representation of Black Speech in American Fiction. London and Toronto: Associated University Presses, 1984.

House, Juliane. “On the Limits of Translatability.” Babel19.4 (1973): 166-167.

Jenkins, Henry. Convergence Culture: Where Old and New Media Collide. New York and London: New York UP, 2006.

Joseph, John Earl. Language and Identity: National, Ethnic, Religious. Basingstoke: Palgrave Macmillan, 2004.

Labov, William. Language in the Inner City: Studies in the Black English Vernacular. Philadelphia: U of Pennsylvania P, 1972.

Landers, Clifford E. Literary Translation: A Practical Guide. Clevedon and Buffalo: Multilingual Matters, 2001.

Leech, Geoffrey, and Mick Short. Style in Fiction: A Linguistic Introduction to English Fictional Prose. Harlow: Pearson Longman, 2007.

Lefevere, André. Translation, Rewriting and the Manipulation of Literary Fame. London and New York: Routledge, 1992.

Mace, Renate. Funktionen des Dialekts im regionalen Roman von Gaskell bis Lawrence. Tübingen: Gunter Narr, 1987.

McDowell, Tremaine. "The Use of Negro Dialect by Harriet Beecher Stowe." American Speech 6.5 (June 1931): 322-326.

Minnick, Lisa Cohen. Dialect and Dichotomy: Literary Representations of African American Speech. Tuscaloosa: U of Alabama P, 2004.

Morgan, Marcyliena, ed. Language and the Social Construction of Identity in Creole Situations. Los Angeles: Center for African-American Studies Publications, 1994.

---. Language, Discourse and Power in African American Culture. Cambridge: Cambridge UP, 2002.

Mpoche, Kizitus, and Tennu Mbuh, eds. Language, Literature and Identity. Göttingen: Cuvillier, 2006. 
Paul, Heike. Kulturkontakt und Racial Presences: Afro-Amerikaner und die deutsche Amerika-Literatur, 1815-1914. Heidelberg: Winter, 2005.

Pederson, Lee. East Tennessee Folk Speech: A Synopsis. Frankfurt am Main: Lang, 1983.

Pym, Anthony. Exploring Translation Theories. London and New York: Routledge, 2010.

Snell-Hornby, Mary. Translation Studies: An Integrated Approach. 1988. Amsterdam and Philadelphia: John Benjamins, 1995.

Sundquist, Eric J., ed. New Essays on Uncle Tom's Cabin. Cambridge: Cambridge UP, 1986.

Venuti, Lawrence. The Translator's Invisibility: A History of Translation. 1995. London and New York: Routledge, 2008.

Wolfram, Walter A. A Sociolinguistic Description of Detroit Negro Speech. Washington, DC: Center for Applied Linguistics, 1969. 